\title{
Thematic Learning Based on Gender Equality and Value of Diversity to Strengthen Student National Character
}

\author{
Mardhatillah $^{1}$, Siti Mayang Sari ${ }^{2}$, Herman Dwi Surjono $^{3}$, Ali Muhtadi ${ }^{4}$ \\ \{mardhatillah.atjeh@gmail.com ${ }^{1}$,sitimayangsari30@gmail.com², hermansurjono@uny.ac.id ${ }^{3}$ \\ alimuhtadi@umy.ac.id $\left.{ }^{4}\right\}$ \\ ${ }^{1,2}$ STKIP Bina Bangsa Meulaboh, Meulaboh, Aceh Barat, Indonesia \\ ${ }^{3,4}$ Universitas Negeri Yogyakarta, Yogyakarta, Indonesia
}

\begin{abstract}
In preparing golden Indonesia in 2045, education role becomes prominent especially in building the national character of students, in which without this aspect, it is very difficult to create a good civilization. Therefore to create a golden generation, some important traits are needed including upbringing, education, and training received from an early age so that students' abilities and characters grow and develop in the best way to fulfill the dreams of the Indonesian golden generation. So far, learning activities in elementary schools has not been able to form an individual that reflects the nation's character and culture. Hence this study aims to create learning that based on gender equality and the value of diversity among students in Aceh, through the development of learning models. Thematic learning combines many subjects into one theme and integrates gender equality and the value of diversity in learning are some models applied. Thematic learning becomes one of the alternatives to develop and form students' characters that bring the dignity of the nation as well as can be proud of before other nations
\end{abstract}

Keywords: thematic learning, gender equality, the value of diversity

\section{Introduction}

Character building begins from elementary school as the most basic that can be an initial milestone in the student character building. [1]. Education is expected to produce quality and developing human beings who can be developed for national development. The implementation of the 2013 curriculum identifies that learning in schools places more emphasis on aspects of the learning experience that are suited to students' talents and interests. In addition, the 2013 curriculum states that the preparation and development of learning activities must pay attention to the principles of drafting and development in accordance with the conditions in the education unit both students' initial abilities, interests, learning motivation, talents, potential, social abilities, emotions, learning styles, special needs, speed learning and others [2].

Thematic learning is a recommended learning model of the 2013 curriculum. In its learning, thematic combines several subjects into an active object, namely the real world of students into one activity [3]. Thematic learning helps teachers to improve professionalism. This is because thematic learning requires carefulness and seriousness in determining themes consistently and able to develop assessment instruments that are relevant to learning activities. 
Gender and thematic learning based on diversity is thematic learning that includes elements of gender and diversity at each stage of thematic learning developed. Problems that occur in the field are (1) the lack of teacher understanding in developing thematic learning in the classroom; (2) lack of student nationalism; (3) lack of students' understanding of gender equality. Justice and equality are the basic ideas, goals and main mission of human civilization to achieve prosperity, build harmony in community and state life to build quality families [4]. The realization of gender equality and justice is identified by the absence of discrimination between women and men so that they have access, opportunities to participate and control over development and obtain equal and fair benefits from development.

Gender relations are social relations between males and females that are mutually helping or vice versa and have many differences and inequalities. Gender relations differ from time to time, and between one community and another, due to differences in ethnicity, religion, social status and values (traditions and norms adopted) [5] through an understanding of gender equality, students are expected to respect the opposite sex more and recognize equal rights and obligations as students in schools so that there is no discrimination [6].

\section{Research methods}

The method used in this research is the research and development method. This research produced a product of a gender-based learning model and diversity for fourth-grade students of an elementary school in the district of West Aceh. This research has the following stages: (1) preliminary study, (2) design and development stage, and (3) testing phase. The learning design model used is the ADDIE model, which is a learning design model that has the basic stages of learning system design that is easy to understand and simple. The location of the study was the Public Elementary School in Aceh Barat District, Aceh Province. The data collection and analysis techniques are quantitative data obtained from the results of validation by learning model experts. The data analysis technique used is descriptive statistics.

\section{Result and discussion}

The learning model design was validated by 3 (three) learning design experts. Expert validation data obtained based on the learning design expert's evaluation through the learning model validation sheet. The validation results of the learning design expert are presented as follows on the Tabel 1 below.

Table 1. Learning model validation results

\begin{tabular}{|c|c|c|c|c|}
\hline \multirow[t]{2}{*}{ no } & \multirow{2}{*}{ indicator } & \multicolumn{3}{|c|}{ rating score } \\
\hline & & V1 & V2 & V3 \\
\hline 1 & $\begin{array}{c}\text { Containing a framework describing thematic learning models } \\
\text { based on gender equality and diversity }\end{array}$ & 3 & 2 & 2 \\
\hline 2 & $\begin{array}{c}\text { Containing the principles of gender-based thematic learning } \\
\text { design models and diversity as a whole theory, goals, procedures, } \\
\text { and contextual. }\end{array}$ & 2 & 3 & 3 \\
\hline 3 & Using grand theory from experts & 3 & 3 & 3 \\
\hline 4 & Containing the objectives of thematic learning design model & 3 & 3 & 3 \\
\hline
\end{tabular}




$\begin{array}{cccc}\text { based on gender equality and diversity } & & & \\ 5 & \text { Containing the step of thematic learning design model based on } \\ \text { gender equality and diversity } & 2 & 3 & 3 \\ 6 & 3 & 3 & 3 \\ \text { Under the context of the student environment } & 16 & 17 & 17 \\ \text { Total } & 50 & & \\ \text { Amount } & 16 & \\ \text { Average } & 16\end{array}$

From the above data, it is obtained that the average score given by the validator is 16 with a total number of 50, this shows the learning design model expert, the learning model developed is worth testing after being improved according to the input of 3 (three) validators. By using a range of score from 1 to 3 , the learning design assessment scores for aspects are assessed using the formula:

$$
\begin{aligned}
& \mathrm{AP}=\underline{\text { Actual Score } X 100 \%} \\
& \text { Ideal Score } \\
& \mathrm{AP}=\frac{16}{18} \times 100 \% \\
& \mathrm{AP}=88 \%
\end{aligned}
$$

After inserting the formula above, the scores obtained from the results of the expert learning model validator are categorized as "high" with intervals between $81 \%$ and $100 \%$. This developed learning model shows that the category is practical to be used with some improvements by validators 1,2 and 3. Some improvement comments from the validator are as follows: (1) strengthening the theory underlying the learning model, (2) showing more about gender, and (3) the diversity is more adapted to the diversity that occurs with the student environment.

The developed learning model gets input from the validator through an evaluation of the validation questionnaire, then the input is used as an improvement material for the developed learning model. After revising the learning model, the learning model is ready and practical to be applied for learning in the fourth grade of the public elementary school in West Aceh, Aceh. The thematic learning model builds upon gender and diversity is a solution to the problems of learning in elementary schools, especially about the declining character of students who do not appreciate the diversity of ethnicities and cultures in Indonesia.

Indonesia consists of many ethnic, ethnic and cultural groups which should be a potential strength of Indonesia's progress if it can create unity and harmony between one citizen and another. West Aceh is a district in Aceh Province that is inhabited by various tribes, including Acehnese, Javanese, Aneuk Jamee, Tiong Hoa, and other tribes. This shows that the West Aceh has residents who have a wide variety of tribes and cultures. Through this learning model based gender and diversity, it is expected that elementary school students in West Aceh can respect and honor each other's various tribes, and also respect the opposite sex so that gender does not occur in classroom learning.

Thematic learning steps can be developed according to the needs of the teacher and the needs of students, through the development of thematic learning models can produce a variety of thematic learning with each various characteristics with the main goal of producing effective and meaningful learning. [7] Teachers as the motor of learning should be able to develop existing learning models so that learning does not seem monotonous and boring [8]. 
Through the learning model build upon gender and diversity by producing a learning model guidebook for students and teachers, has shown the achievement of the objectives of developing the model as it should, students seem to understand well the differences around them and mutual respect between one another. Previously students play in groups, through this learning model students are accustomed to heterogeneous groups, both ethnicity, language, and competence. So students can share. The student's study with heterogeneous groups will form characters of mutual care and sharing [9]. Meaningful learning will be obtained when students participate in learning enthusiastically and excitedly, this certainly requires the teacher to be more creative in managing to learn in the classroom. [10]

\section{Conclusion}

This research produces a learning model to build upon gender and diversity. After going through the validation process by learning model experts, a learning model is produced that is practical to be implemented in the fourth grade of public elementary schools in West Aceh, Aceh. Learning models build upon gender and diversity contain ethnic and cultural values that exist in the district of West Aceh, and contain the values of gender equality. It aims to make students able to appreciate the differences that exist in their school. In general, it aims to create a sense of student nationalism. Thus, it can be summed up that the learning model builds upon gender and diversity developed is practical to be implemented in primary schools in West Aceh with some revisions.

Acknowledgments. This research was funded by the General Director of Research and Community Service, Ministry of Research and Higher Education for the budget of 2019. This research is collaborative research between STKIP Bina Bangsa Meulaboh and Yogyakarta State University.

\section{References}

[1] Y. D. Ariyani and M. N. Wangit, "Pengembangan Bahan Ajar Tematik-Integratif Berbasis Nilai Karakter Peduli Lingkungan Dan Tanggung Jawab," J. Pendidik. Karakter, vol. 6, no. 1, pp. 116-129, 2016.

[2] D. N. L. Laksana, P. A. W. Kurniawan, and I. Niftalia, "Pengembangan Bahan Ajar Tematik Sd Kelas Iv Berbasis Kearifan," vol. 3, no. 1, pp. 1-10, 2016.

[3] A. A. Siswoyo, F. I. Pendidikan, and U. T. Madura, "Pengembangan Perangkat Pembelajaran Tematik Berbasis Quantum Learning Berdasarkan Pendekatan Saintifik," pp. 33-43.

[4] W. S. Tune, "Implementasi Kesetaraan Gender Dalam Bidang Pendidikan Warni Tune Sumar," Musawa, vol. 7, no. 1, pp. 158-182, 2015.

[5] Z. A. MZ, "Perspektif Gender Dalam Pembelajaran Matematika," Marwah J. Perempuan, Agama dan Jender, vol. 12, no. 1, p. 15, 2013.

[6] S. C. Dilla, W. Hidayat, and E. E. Rohaeti, "Faktor Gender dan Resiliensi dalam Pencapaian Kemampuan Berpikir Kreatif Matematis Siswa SMA,” J. Medives J. Math. Educ. IKIP Veteran Semarang, vol. 2, no. 1, p. 129, 2018.

[7] D. Setiawan, "Authentic Assessment Model in Social Studies Learning To Improve the Social Skills," Turkish Online J. Des. Art Commun., vol. 7, no. December, pp. 1393-1403, 2017.

[8] H. T. Atmaja, "Konstruksi Sosial Pembelajaran Ips Berbasis Kebangsaan ( Studi Fenomenologi Pada Guru Pendidikan IPS )," vol. 1, no. 1, pp. 300-305, 2017.

[9] S. Panjaitan and P. Berkarakter, "Pengaruh Model Pembelajaran Arias Dalam Meningkatkan Hasil Belajar," vol. 1, no. 1, pp. 321-323, 2017. 
[10] M. Mardhatillah, V. Verawati, E. Eviyanti, and I. Pramuniati, "The Effect of Teaching Materials Based on Aceh 's Local Wisdom on Student Learning Results of Junior High School in Aceh Province,” Britain Int. Humanties Soc. Sci. J., vol. 1, no. 2, pp. 192-199, 2019. 